\title{
Láska jako srdce teologie
}

\author{
František Štěch
}

Je to "živý plamen lásky", který žhne v "nejhlubším středu mé duše", nebot" "středem mé duše je Bưh".

(Sv. Jan od Kř́že)

A za to se modlím, aby se vaše láska ještě víc a více rozhojňovala a s ní i poznání a hluboká vnímavost; abyste rozpoznali, na čem záleží, a byli ryzi a bezúhonní pro den Kristův, plní ovoce spravedlnosti, které $z$ moci Ježíše Krista roste $k$ slávě a chvále Boží.

Láska (caritas) je srdcem řeči o Bohu (teologie), píše ve svém článku, který přináší aktuální číslo tohoto magazínu, Markus Lehner. Je tomu skutečně tak? A jak souvisí křest́anská charita s teologií? Jaké jsou možnosti jejího systematicko-teologického zakotvení? Charita je slovo, které používáme pro jakékoliv skutky křest'anské lásky. V posledních dvou stoletích se charita mimo jiné stává postupně synonymem pro různé formy institucionalizované pomoci potřebným, jež nacházejí svůj zdroj v křest'anském životě těch, kteří se jí věnují. ${ }^{1} \mathrm{O}$ tom, že tato praxe potřebuje svou vědeckou reflexi, není sporu a svědčí o tom i tzv. věda o charitě (Caritaswissenschaft), která se institucionalizovala na mnoha (zejména německých) univerzitách v průběhu 20. století. Nicméně, jak připomíná Michal Opatrný: „Ovšem ani ne tak teologie jako rozumová reflexe víry, ale křstanství coby praxe víry je neopomenutelným zdrojem, ze kterého vzešly pomáhající profese. " ${ }^{2} \mathrm{~V}$ přítomném textu se pokusíme podívat se na celou problematiku nikoliv pohledem praxe víry, ale z hlediska její rozumové reflexe, přesněji z hlediska fundamentální teologie. Co je tou základní pohnutkou, která vede křest'ana rozpoznávat druhé jako své bližní a starat se o chudé a trpící? Jaký je zdroj institučně zakotvené charitní práce? V jakém vztahu je křest'anská „„caritas“ ke křest'anskému zjevení, víře a ke společenství těch, kteří vyznávají Kristovo jméno?

\section{Boží zjevení jako zjevení Lásky}

Samotné slovo „zjeveni" (lat. revelatio (revelare); podobně např. ang. Revelation) je slovesné podstatné jméno odvozené od slovesa „zjevit“ (zjevit se). Již samo slovo ukazuje, že jde o jakési odhalení dosud neznámých či ne zcela zřejmých skutečností. Latinské "revelatio", podobně jako řecké „apokalypsis“ (apokalyptein) znamená „odhalení něčeho co bylo dosud zakryto“, doslo-

\footnotetext{
${ }^{1}$ Srov. Rudolf SvoBodA, „Sociální práce a křest'anství" (kap. 1.1 - 1.1.7), in Teorie a praxe charitationí práce, (eds.) Michal Opatrný, Markus Lehner, České Budějovice: Jihočeská Univerzita v Českých Budějovicích, Teologická fakulta, 2009, s. 9-24.

${ }^{2}$ Michal OPATRNÝ, "Jak uvažovat o charitativní práci“, in Teorie a praxe charitationí práce, (eds.) Michal Opatrný, Markus Lehner, České Budějovice: Jihočeská Univerzita v českých Budějovicích; Teologická fakulta, 2009, s. 7.
} 
va „odstranit roušku. “3 V náboženském smyslu se jedná o zjevení tajemství, které v sobě skrývá zpravidla řád fungování světa, smysl veškeré existence nebo jiné skutečnosti lidskému poznání běžně skryté. Křest'anským jazykem proto můžeme zjevení velmi obecně charakterizovat jako Boží svobodnou aktivitu [DV2], ${ }^{4}$ která odhaluje člověku to, co leží za hranicemi možností jeho poznání a zve ho tím do vztahu [DV6]. Uvěřit znamená být uveden do vztahu s posvátnem. Nadpřirozeno se zjevuje člověku a člověk na toto zjevení odpovídá svou vírou, která hledá své sdílení a realizaci ve společenství věřících. Na rovině křest'anství je to zkušenost se Zmrtvýchvstalým, která vede nového křest́ana ke specifické víře i k afiliaci s některou křest'anskou denominací. Zjevení tedy zakládá vztah mezi Zjevovatelem a př́ijemcem zjevení, mezi Bohem a člověkem.

Z jakého důvodu se však Bůh člověku zjevuje? Snad bychom to mohli zjednodušeně přirovnat k vyznání lásky, kdy jeden druhému sděluje své city a očekává kladnou, avšak může dostat i zápornou odpověd'. Stejně tak i Boží pozvání člověka do vztahu vyžaduje lidskou odpověd' - pozitivní odpověd' víry či negativní odpověd' nevíry [srov. DV5]. Obě dvě varianty jsou v rámci realizace lidské svobody možné. Tato možnost svobodného rozhodnutí pro Boha nebo proti Bohu je zakotvena již v samotném řádu stvoření. „Proním Božím zjevením je sám stvořitelský čin. Jím projevil Bůh svou lásku a moudrost a svou moc. Všemu tvorstou vložil nejhlubši tajemství a nejoyšši cíl - zaměrení k Tvưrci. Svým stvořitelským slovem ustavil pravdu a smysl (logos) tvorstva, svou láskou a svatostí - možno-li tak říci - vložil tvorstou nezrušitelnou touhu po jednotě, tíhnutí k plnosti. " ${ }^{5}$ Toto "prootni, obecné zjeveni" se dále rozvijí v dějinách, na jejichž pozadí můžeme pozorovat různé události, rozpoznávané věřícími jako zjevení „zvláštni". Sled (dějiny) těchto "zvláštních zjeveni" můžeme nazvat dějinami spásy. ${ }^{6}$ Různí autoři v dějinách se pak pokusili načrtnout jejich strukturu. Jedním z nich byl i Oscar Cullmann. Pro něj má Boží zjevení zásadně soteriologický charakter. Bůh se tedy lidem zjevuje proto, aby poznali pravdu o smyslu svého bytí, kterým je spása. Jinými slovy, aby sdělil svou Lásku k člověku a povolal jej rovněž k Lásce. Tato „Láska“, neboli stvořitelský Logos, vtělený, zmrtvýchvstalý i eschatologických Kristus ${ }^{7}$ je právě schématem a principem takto pojímaných dějin spásy.

Na počátku je tedy vše stvořeno z Boží Lásky a skrze tuto Lásku (Krista - Logos), toto „stvořitelské zjeveni" Boží Lásky rozehrává její spásně-dějinnou dynamiku. Na jejím počátku stojí pokřivení láskyplného vztahu mezi Bohem a lidmi kvůli pýše prvního hříchu. Trapné a osudové ustrnutí lidské lásky je však překonáno ze strany Boha „zaslíbením“, které je pak v dějinách Izraele mnohokrát opakováno a také konkretizováno činem - smlouvou. ${ }^{8}$ Celé dějiny starozákonního Izraele jsou dějinami ujištování člověka o trvající boží Lásce a to jediné, co Bůh po lidech vyžaduje, je zase jen jejich láska. Naplněním všech starozákonních Božích zaslíbení je dále v dějinách událost Ježíšovy smrti a zmrtvýchvstání. Skrze zmrtvýchvstalého Krista celé stvoření nachází znovu svou rovnováhu a smíření s Bohem. Je to právě Ježíš, který spojuje Boží požadavek lásky ze strany člověka s přikázáním lásky ke všem lidem [srov. DCE 1]. ${ }^{9}$ Lidská láska však již není pouze požadavkem či přikázáním, láska člověka má být výrazem odpovědi na Boží Lásku, na pozvání do vzájemného vztahu. Plán dějin spásy se uzavírá

\footnotetext{
${ }^{3}$ Srov. Avery Dulles, Revelation Theology. A History, New York: Herder \& Herder, 1969, s. 9. Dále srov. Avery Dulles, „Víra a Zjevení“, in Systematická teologie 1. Řimskokatolická perspektiva, (eds.) Francis Fiorenza, John Galvin, Brno, Praha: CDK, Vyšehrad, 1996, s. 105.

${ }^{4}$ Dokumenty II. vatikánského koncilu, Kostelní Vydří: Karmelitánské nakladatelství, 2002. Konstituce Dei Verbum. Dále v textu pouze DV a číslo příslušného oddílu.

${ }^{5}$ Josef ZvĚřınA, Teologie Agapé I, Praha: Scriptum, 1992, s. 77-78.

${ }^{6}$ Srov. Tamtéž, s. 78.

7 Srov. Oscar Cullmann, Christ and Time; the primitive Christian conception of time and history, Philadelphia: The Westminster Press, 1964, s. 179.

${ }^{8}$ Srov. Josef ZvĚřInA, Teologie Agapé I, Praha: Scriptum, 1992, s. 78.

${ }^{9}$ BenedikT XVI, Deus caritas est, Praha: Paulínky, 2006, Dále v textu pouze DCE a číslo příslušného oddílu.
} 
událostí jejich eschatologického završení. „V něm se zjeví láska Boží i láska lidská. Spojení pravdy, spravedlnosti, svatosti a lásky bude plnost života." "Zjevení je proní pravda, proní tajemstoí (mystérium) a proní kategorie křest'anství;" 11 píše ve své teologii zjevení René Latourelle. Zjevení tedy můžeme považovat za samotný základ (fundament) křest́anské teologie. V předchozím textu jsme (nejen) spolu s předním českým "teologem lásky“ viděli, že Boží zjevení lze pojímat jako zjevní Lásky. Vrcholem a úplností tohoto zjevení Lásky je událost Ježíše Krista. „Bůh tak miloval svět, že dal svého jednorozeného Syna, aby žádný, kdo v něho věři, nezahynul, ale měl život věčný" [Jan 3,16]. Kdo zůstává v Kristu, zůstává v samotném Trojjediném, který je Láska, a tedy zůstává v Lásce. V církvi často užívané klišé: „Bůh je láska“ zde získává zcela jiný rozměr zásadního významu. Tento rozměr bych si dovolil nazvat spolu s Karlem Skalickým „ontologicky transformačni. “ 12 Zmrtvýchvstalý Ježíš je totiž jakousi první vlaštovkou druhého stvoření a začíná působit jako kvas $\mathrm{v}$ dějinách stvoření prvního. Začíná postupně přetvářet zevnitř první stvoření na stvoření druhé, které bychom mohli identifikovat s tzv. "Božím královstvím“. To je již nějak přítomné, ale ještě není uskutečněné ve své plnosti. Sv. Pavel k tomu říká: „Kdo je v Kristu, je nové stvoření. Co je staré, pominulo, hle, je tu nové!" [2 Kor 5, 17]. Kdo je v Kristu, má již podíl na novém stvoření. Zatímco tedy první Adam pojedl ze stromu poznání, nové stvoření pojí ze stromu života. Boží zjevení by dle mého názoru nemělo tento ontologicky transformační náboj, kdyby nebylo především zjevením Lásky. „Bůh je láska; $k d o$ zůstává v lásce, zůstává v Bohu a Buh zůstává v něm" [Jan 4,16].

\section{Víra člověka jako odpověd' na zjevení Lásky}

Náboženskou terminologií může být víra, ve svém nejširším slova smyslu, popsána jako jakákoliv lidská odpověd' na Boží zjevení. V katolické systematické teologii se o viřre hovoří povětšinou jako o vědění či vědomí Boha, které je vlastní lidskému životu, a proto má pouze omezené trvání. ${ }^{13}$ Víra v pojetí biblických náboženství pak označuje zpravidla spásonosný vztah Boha a Jeho stvoření, které odpovídá na Jeho zjevení. Tento vztah jedince ke zjevení se pak realizuje plně ve společenství věřících, které nazýváme církví. Zde je však třeba varovat se obou extrémních pozic. Obě polohy či oba rozměry víry (kolektivní a individuální) musí být ve vzájemné rovnováze. Křest'anství je náboženství po výtce společenské, a proto dochází individuální vztah každého věřícího s Bohem svého naplnění ve společenství věřících. V katolickém křest'anství můžeme říci: ve společenství Eucharistie. Samo zjevení v judaismu i křest'anství má silný sociální charakter. Bůh v judaismu nabízí lidu smlouvu a lid Izraele je pak lidem víry v Boží zaslíbení. Křest'anství pak vzniká jako "náboženství nové smlouvy“ a křest'ané jsou „lid nového zákona“. Z tohoto pohledu můžeme víru chápat také jako nadpřirozený dar, tedy ne jen jako rozhodnutí, postoj či aktivitu člověka. Na rovině víry totiž dochází k vlastní, reflektované interakci stvoření se svým stvořitelem, a to právě na úrovni jejich láskyplného vztahu, který může vést až k vzájemné jednotě [srov. 1 Kor 6,17]. Benedikt XVI. považuje tuto součinnost dokonce za vyjádření esence biblické víry: "Ano, existuje sjednocení člověka s Bohem - tento prapưvodni sen člověka. Toto sjednocení však neni vzájemným slitím, není to utonutí v bezejmenném oceánu božství, protože se jedná o jednotu, kterou tvoři láska, v níž bůh i člověk zůstávají každý sám sebou, a přece se stávají jednotou /.../ [DCE 10]."

\footnotetext{
${ }^{10}$ Josef ZvĚ̌̌inA, Teologie Agapé I, Praha: Scriptum, 1992, s. 79.

${ }^{11}$ René Latourelle, Theology of Revelation, Staten Island, New York: Alba House a division of St. Paul Publications, 1966, s. 14.

${ }^{12}$ Karel SкALICKÝ, „,Geneze koncilního dokumentu o Zjevení“, Teologické texty, 2003, č. 1, s. 22-23.

${ }^{13}$ Srov. Avery Dulles, „,Víra a Zjevení", in Systematická teologie 1. Řimskokatolická perspektiva, (eds.) Francis FiorenZA, John Galvin, Brno, Praha: CDK, Vyšehrad, 1996, s. 117.
} 
Již od počátku křest'ané mají za to, že víra je jediným základem, na němž stojí celý vztah člověka $\mathrm{k}$ Bohu ${ }^{14}$ a také magisterium podložilo toto přesvědčení nespočetnými výroky. Např. I. vatikánský koncil učí: „Protože člověk zcela závisí na Bohu jako na svém Stvořiteli a Pánu a stvořený rozum je zcela podřizen nestvořené Pravdě, máme zjevujícímu se Bohu vírou prokazovat naprostou poslušnost rozumu i vůle. Katolická církev vyznává, že tato víra, která je počátkem lidské spásy, je nad přirozenou ctností, již s podporou a pomocí Boži milosti věřme, že to, co Bůh zjevil, je pravdivé /.../. Víra je podle svědectví Apoštola podstata věcí, v něž doufáme, důkaz toho, co nevidíme (Žid 11, 1)." [srov. DS 3008]. ${ }^{15}$

Víra je tedy pohledem prvního vatikánského koncilu především odpověd' na Boží zjevení, odpověd' prokazující úctu a vzdávající hold všemohoucímu Stvořiteli. Tato víra stojí také u samotných počátků lidské cesty ke spáse [srov. DS 1532] a nakolik je dílem součinnosti působení Boží milosti a lidské odpovědi na zkušenost zjevení, je i nadpřirozenou ctností.

Druhý vatikánský koncil pak v 60. letech 20. století vpodstatě opakuje výroky prvního vatikánského sněmu: "Zjevujicímu se Bohu je třeba prokazovat "poslušnost víry" / .../, již se celý člověk svobodně odevzdává Bohu tím, že se "rozumem i vưlí plně podřizuje zjevujícímu Bohu" (DS 3008) a dobrovolně prìímá zjeveni, které Bůh dal. K tomu, aby se nám dostalo této víry, je potřebná přicházející a pomáhajicí Boží milost a vnitřní pomoc Ducha svatého / .../ , který stále zdokonaluje víru svými dary." [DV 5]. Víra je zde pojímána opět jako dobrovolná, poslušná a úctyplná odpověd' na Boží zjevení zakotvená v proudu Boží milosti a opírající se o pomoc Ducha svatého. Jako taková je tedy víra oživována láskou a nedostatek lásky zase víru poškozuje a zabíjí. Láska se zdá být konečnou realizací lidské víry, je jakousi transformací samoty, nebot' i v osamění lidské srdce cítí, že je Bohem znáno a milováno. Boží mlčení pak není němota, samota není opuštěnost, naopak, víra se stává důvěrou, která dává naději. ${ }^{16}$ Můžeme tedy říci, že lidská víra roste s mírou lásky, která je její energií. Měřítkem proudu energie lásky jsou pak v křest'anském pojetí konkrétní činy - víra se realizuje v konkrétních skutcích. "Ve skutcích došla víra dokonalosti“ [Jak 2,22]. Můžeme tedy shrnout, že lidská, v pravdě křest'anská odpověd' na zkušenost zjevení Lásky je víra, víra, která se uplatňuje láskou [srov. Gal 5,6], láskou k Bohu a ke všem lidem [srov. Žid 6,10].

\section{Služebné pojetí církve jako společenství lásky}

Zmínili jsme, že víra má nejen individuální, ale i kolektivní dimenzi, která je v jistém (teologickém) smyslu naplněním či dovršením lidských projevů lásky. K tomu dochází na půdě církve. Zdůraznění aspektu lásky ve společenství křest'anů vede k tzv. služebnému pojetí církve, kdy sama církev se chápe jako „služebnice“. V tomto smyslu zdůrazňuje vzájemné bratrství lidí všech ras a národů snahou o lepší svět, který se tvoří nasazením jedinců i celých společenství $\mathrm{v}$ jejich bezprostředním okolí. Zvláštní pozornost je též věnována ekologii. Služebné pojetí církve si uvědomuje stvořenost člověka a tedy i jeho zodpovědnost za celý svět a jeho trvale udržitelný rozvoj. Člověk je pojímán jako služebník svého Stvořitele a správce jeho stvoření, spíše než jeho pán. „Úkolem církve pak není nábor nových členů ani zbytečné teoretizování o svátostech, či cílené budování komunit. Primárním úkolem církve je pomoc všude tam, kde je to třeba - slovem, modlitbou, finanční podporou, osobni aktivni pomocí. Církev by měla udržovat ve světě při životě naději

\footnotetext{
${ }^{14}$ Srov. Avery Dulles, „The Modern Dilemma of Faith“, in Michael Mooney, et al. (eds.), Toward a Theology of Christian Faith, New York: P. J. Kennedy \& Sons, 1968, s. 11.

${ }^{15}$ Heinrich DenZINGER, Enchyridion symbolorum definitionum et declarationum de rebus fidei et morum. Kompendium der Glaubensbekenntnisse und kirchlichen Lehrentscheidungen. Lateinisch - Deutsch. Freiburg im Breisgau: Herder Verlag, 1991. Dále v textu pouze DS a číslo př́slušného oddílu.

${ }^{16}$ Srov. Josef ZvĚ̌̌INA, Teologie Agapé I, Praha: Scriptum, 1992, s. 73.
} 
a touhu po Božím království a jeho hodnotách. " 17 Je tedy třeba ty to hodnoty představit a nabídnout světu. Nikoliv však formou vnucování, ale formou služby. To znamená, že se církev musí proměnit ve služebnou instituci, v církev sloužící v lásce a přinášející do tohoto světa obraz zaslíbeného království. ${ }^{18}$

Služebné pojetí církve v katolickém prostředí má dle mého názoru své kořeny v tzv. „kenotické teologii“" [srov. Fp 2,7]. Idea sebezmaření, sebeumenšení či sebezapření až k smrti implikuje pro církev důležitou změnu postoje. "Církev nemůže vládnout silou, ale musí pritahovat láskou." 19 K tomu ji inspiruje sám Ježíš Kristus, ten je ve svém lidství mužem ne pro sebe sama, nýbrž přednostně mužem pro ostatní, a církev, jestliže chce být pravdivou svědkyní jeho výkupné oběti, musí přijmout jeho životní styl - službu ostatním až do krajnosti. ${ }^{20}$ Křest'anská služba je tak především službou Bohu, nebot' křest'ané nemají sloužit ničemu pozemskému. Láskyplné přijetí služebného vztahu k Bohu vede paradoxně do osobní svobody, jeho odmítnutí do otroctví hříchu. Služba Bohu se projevuje v křest'anském životě na mnoha úrovních. Motivem všech forem křestáanské služby je opět láska. Láska jako zjevený Logos, jako Ježíš Kristus, zjevený Zjevovatel, láska jako přijetí zjevení ve víře a konečně i láska sdílená, prožívaná s ostatními v živém a dýchajícím těle Kristově - ve společenství lásky. „Tvář Kristovu můžeme vidět v tváři druhých. Jsme-li s Bohem smírení, jsme-li v lásce Boží, neseme podobu Kristovu ve své duši. Ta se v nezištně dobrém skutku, při setkání s druhým člověkem promitá navenek. Skrze závoj lidské tváre nazíráme něco z Božské krásy Svaté tváře, která mizí v neviditelném světle." ${ }^{21}$

\section{Teologie jako "sciencia caritatis“?}

Vrat'me se však nyní k otázkám, které jsme si kladli na úvod tohoto pojednání. Viděli jsme, že křest'anská charita je zakotvena v samotném zjevení, nebot' typicky křest'anské zjevení můžeme chápat mimo jiné jako "zjevení Lásky". Motivem a principem charity je víra, kterou můžeme s láskou téměř ztotožnit, jak jsme na to poukázali v druhé části přítomné studie. Kolektivní výraz víry, který jsme si dovolili nazvat (možná př́liš troufale, maje na mysli reálný obraz církve) společenstvím lásky, pak vede $\mathrm{k}$ služebnému pojetí víry. To umožňuje realizaci konkrétních forem starosti o chudé a trpící, o lidi bez domova, o lidi postižené povodněmi, o mentálně či sociálně handicapované i o mnohé další, kteří se svými potřebami dotýkají srdcí Kristových učedníků. Jejich „caritas“ je zakotvena v Lásce a je tak zdrojem konkrétní pomoci, která dostává i svou institucionální formu. Teologii můžeme, myslím, v tomto kontextu nazvat skutečně vědou lásky: „scientia caritatis", či chcete-li "Caritaswissenschaft". Její pravý formát není záležitostí knih, konferencí, symposií ani článků jako je tento. Její „vědeckost" spočívá úplně v něčem jiném. Ne v tom, co dnes nazýváme vědou, ale v pravém „věděni", které se odráží v jednání, v hledání př́ležitosti, v níž by se láska (a tím i Láska) mohla projevit. "Scientia caritatis - nestači pouze vědět, že láska je hezká věc, pět ódy na ni, vyslovovat sladce její jméno. To konečně nikdo nepopírá. Ale vědět, kde mohu zapưsobit svou láskou, kde ji mohu uplatnit. Hledat př́ležitosti, kde bych mohl projevit svou lásku k bližnímu, ke každému bez výjimky. Milovat - ne slovy, ale skutky. Milovat - ne jen čekat, ale hledat př́ležitost k projevu lásky." 22

Nezbývá než si přát, aby křest’anská praxe byla účinným vyjádřením křest'anské teologie a tato teologie aby neměla jen plná ústa lásky, ale byla vyvážena aktivitou, odrážející náš život

\footnotetext{
${ }^{17}$ František ŠTĚCH, „A Aby byl Boží lid světlem národi̊“, UNIVERSUM, 2006, č. 2, s. 15-22.

${ }^{18}$ Srov. Avery Dulles, Models of the Church, $5^{\text {th }}$ expanded edition, New York: Image Book, Doubleday Publishers, 2002, s. 90-91.

19 Tamtéž, s. 88.

20 Srov. tamtéž, s. 216.

${ }^{21}$ Karel ŘítHA, Hledání středu, Svitavy: Trinitas, 2010, s. 74.

22 Vladimír Boublík, Duchovní deník, Olomouc: Refugium, 2010, s. 125.
} 
v Lásce, aby byla skutečnou „vědou lásky“. Profesor Erazim Kohák mi kdysi v rozhovoru řekl, že spása pro něj znamená Boží uschopnění člověka k tomu, aby dokázal dělat to, o čem již ví, že to dělat má, nicméně není toho zcela schopen. Mám za to, že je to láska, co zde má Erazim Kohák na mysli. Láska, která nejen osvobozuje, ale též Láska, která spasí.

\begin{abstract}
:
Is love (caritas) the heart of theology? The central question of this article is studied from three fundamental theological perspectives. First of them is revelation as revelation of Love, which is the principle of the Divine - human relationship. Second is human faith as response on revelation of Love and third perspective deals with the Church as community of love and charity. All three studied aspects points towards question if theology as such is the "sciencia caritatis". Theology is science not in the strict sense of the word, but in much broader perspective it can be true knowledge and wisdom moving the person towards concrete acts of love towards the others. True theology searches for ways how concrete love can be realized and true Love can enter the hearts of people.
\end{abstract}

Key words: Theology, Love, Revelation, Faith, Church 